\title{
Calixarenes: Versatile molecules as molecular sensors for ion recognition study
}

\author{
SUBRATA PATRA, DEBDEEP MAITY, RAVI GUNUPURU, PRAGATI AGNIHOTRI and \\ PARIMAL PAUL*
}

Analytical Science Division, Central Salt and Marine Chemicals Research Institute (constituents of CSIR, New Delhi), G B Marg, Bhavnagar 364 002, India

e-mail: ppaul@csmcri.org

\begin{abstract}
This article presents a brief account on designing of calixarene-based molecular sensor for recognition of various metal ions and anions and also different analytical techniques to monitor the recognition event. This review focuses only on calix[4]arene derivatives, in which mainly the lower rim is modified incorporating either crown moiety to make calix-crown hybrid ionophore to encapsulate metal ions or some fluoregenic inorganic and organic moieties to use it as signalling unit. In order to investigate effect of conformation of the calixarene unit and steric crowding on ion selectivity, designing of these molecules have been made using both the cone and 1,3-alternate conformations of the calixarene unit and also incorporating bulky ter-butyl group in few cases to impose controlled steric crowding. Among various ions, here focuses are mainly on biologically and commercially important alkali metal ion such as $\mathrm{K}^{+}$, toxic metal ions such as $\mathrm{Hg}^{2+}, \mathrm{Pb}^{2+}, \mathrm{Cd}^{2+}$, important transition metal ion such as $\mathrm{Cu}^{2+}$ and toxic anion like $\mathrm{F}^{-}$. The techniques used to monitor the recognition event and also to determine binding constants with strongly interacting ions are fluorescence, UV-vis and ${ }^{1} \mathrm{H}$ NMR spectroscopy. Most of the ionophores reported in this review have been characterized crystallographically, however no structural information (except one case) are incorporated in this article, as it will occupy space without significant enhancement of chemistry part. Different factors such as size of the ionophore cavity, size of metal ion, coordination sites/donor atoms, steric crowding and solvents, which determine selectivity have been discussed. Response of ion recognition process to different analytical techniques is another interesting factor discussed in this article.
\end{abstract}

Keywords. Molecular sensor; calixarene; ion recognition; fluoroionophores; supramolecular chemistry.

\section{Introduction}

Design and synthesis of functional molecules that could serve as molecular devices for sensing of specific ion is an area of intense activity in current research. ${ }^{1}$ Different types of organic molecules have been used as ionophore to design molecular sensor, however, macrocyclic ligands are excellent choices for this purpose because of their remarkable selectivity towards various metal ions. In this regard, calixarenes, which are macrocyclic oligomers made up of phenol units linked by methylene bridge are found to be very attractive because of their ability to bind variety of ions. ${ }^{1,2}$ In the calixarene family, calix[4]arenes are most popular because of their rigid structures, which make them ideal candidates for the complexation with metal ions (1) ${ }^{2-4}$ Both the upper and lower rims of the calixarene can be modified depending on the requirement and these modified calixarenes provide a highly preorganized architecture for the assembling of converging binding sites.

\footnotetext{
*For correspondence
}

Ion-selectivity of the calixarenes are controlled by different factors such as conformation of the calix moiety (2), binding sites, size of the ionophore cavity, steric crowding, solvent used and also response of the recognition event to different analytical techniques. We have been working in this area for last few years and have synthesized series of new molecular sensors incorporating calix[4]arene derivatives as ionophore. ${ }^{5-10}$ The ion-recognition property of all these molecules has been investigated with a wide range of cations and anions and the recognition event was monitored by various spectroscopic techniques. On the basis of our study, we report here a brief account of the various aspects of design and ion-selectivity of calixarene derivatives as molecular sensor.

\section{Design of receptors for selective recognition of alkali and alkaline earth metal ions}

For the recognition of alkali and alkaline earth metal ions, a new class of hybrid molecule has been developed incorporating crown ethers into calix[4]arene..$^{5,6,8,11}$ The 
Table 1. Selectivity ratio with respect to potassium ion in the extract and association constant $\left(K_{a}\right)$ for $\mathrm{Na}^{+}$and $\mathrm{K}^{+}$.

\begin{tabular}{lcccccc}
\hline & \multicolumn{3}{c}{$\begin{array}{c}\text { Selectivity } \\
\text { ratio }\end{array}$} & & & \multicolumn{2}{c}{$\begin{array}{c}\text { Association } \\
\text { constants }\left(K_{a}\right)\end{array}$} \\
\cline { 2 - 4 } \cline { 6 - 7 } Compound & $\mathrm{K}^{+} / \mathrm{Na}^{+}$ & $\mathrm{K}^{+} / \mathrm{Mg}^{2+}$ & $\mathrm{K}^{+} / \mathrm{Ca}^{2+}$ & & $\mathrm{Na}^{+}$ & $\mathrm{K}^{+}$ \\
\hline 3a & 1.7 & 12.2 & 6.0 & & $1.06 \times 10^{4}$ & $1.82 \times 10^{6}$ \\
3b & 1.2 & 16.5 & 4.9 & & $8.70 \times 10^{4}$ & $3.25 \times 10^{5}$ \\
3c & 0.3 & - & 1.4 & & $5.17 \times 10^{4}$ & - \\
3d & 2.7 & - & - & & $3.12 \times 10^{6}$ & $7.20 \times 10^{7}$ \\
3e & 1.5 & 60.9 & 16.9 & & $5.96 \times 10^{6}$ & $5.80 \times 10^{7}$ \\
\hline
\end{tabular}

${ }^{a}$ The ratio is calculated by $\left[\%\right.$ of $\mathrm{K}^{+}$in the extract][\% of $\mathrm{M}^{n+}$ in the original solution] $/\left[\%\right.$ of $\mathrm{M}^{n+}$ in the extract][\% of $\mathrm{K}^{+}$in the original solution].

ion selectivity of this class of compounds is mainly depend on the conformation of the calixarene platform, the size of the crown ether ring, the substituents at the upper rim of the calixarene and the appended functional groups at the two sides of the crown ring. Among various conformations of the calixarene, 1,3alternate conformers have been studied more extensively as complexing agent for alkali-metal ions. ${ }^{12}$ Regarding size of the ionophore, the cavity containing crown-5 and crown-6 are found more suitable for complexation, specially for $\mathrm{Na}^{+}$and $\mathrm{K}^{+} .{ }^{5,6,12}$ As part of our effort to develop suitable molecules for selective extraction of $\mathrm{K}^{+}$from natural sources such as brine and bittern, which mainly contain $\mathrm{Na}^{+}, \mathrm{K}^{+}$, $\mathrm{Ca}^{2+}$ and $\mathrm{Mg}^{2+}$, a series of receptors containing $p$-tertbutylcalix[4]arene-crown-5 were designed and synthesized. ${ }^{5}$ To impose controlled steric crowding and also to investigate the effect of substituents at side arms (like 'lariat' crown ether), a number of substituents $\left(\mathrm{H}, \mathrm{COCH}_{3}, \mathrm{CH}_{2} \mathrm{CO}_{2} \mathrm{C}_{2} \mathrm{H}_{5}\right.$ and $\left.\mathrm{CH}_{2} \mathrm{CO}_{2} \mathrm{H}\right)$ appended at the opposite phenolic oxygen atoms of the crown moiety are incorporated (3a-3e). Selectivity of these ionophores towards $\mathrm{Na}^{+}, \mathrm{K}^{+}, \mathrm{Mg}^{2+}$ and $\mathrm{Ca}^{2+}$ were evaluated with aqueous solution containing equimolar mixture of these ions (table 1). The concentration of metal ion in the extract (organic phase) has been estimated by ion chromatographic assay. Among these ions, $\mathrm{K}^{+}$showed highest selectivity in all cases, except in one case where access to the metal ion is blocked off as a result of strong $\mathrm{C}-\mathrm{H}$... O interactions among the pendant $\mathrm{COCH}_{3}$ substituents and crown moiety (figure 1). All the ionophores show poor selectivity towards $\mathrm{Mg}^{2+}$ and $\mathrm{Ca}^{2+}$. Association constants $\left(K_{a}\right)$ for the binding of $\mathrm{Na}^{+}$and $\mathrm{K}^{+}$to these ionophores have been determined spectrophotometrically and it follows the same order as selectivity (table 1). Single crystal
$\mathrm{X}$-ray structure determination of the ionophores and their $\mathrm{Na}^{+}$and $\mathrm{K}^{+}$complexes provides an insight about the structure-selectivity correlation and the effect of intramolecular interactions on complexation. Crystal structures of the metal complexes revealed that the $\mathrm{K}^{+}$ ion fits well in the cavity making interaction with all the eight oxygen donor atoms forming strong complexes whereas $\mathrm{Na}^{+}$ion is coordinated with six oxygen atoms leaving two uncoordinated, suggesting that the size of the $\mathrm{Na}^{+}$does not fit well in the cavity to make interaction with all the oxygen donors (figure 2). Crystal structures also show that in all cases one of the two appended substituents coordinates with the metal ion. The finding from crystal structures is therefore, consistent to the order of selectivity and association constants determined experimentally. The size matching factor and intra/intermolecular interaction are, therefore play an important role to determine selectivity.



Figure 1. Capped stick model of compound 3c, showing $\mathrm{C}-\mathrm{H} . . . \mathrm{O}$ interactions (dotted line) involving methyl hydrogen atoms of $\mathrm{COCH}_{3}$ groups and oxygen atoms (O6 and O8) of the crown moiety. 


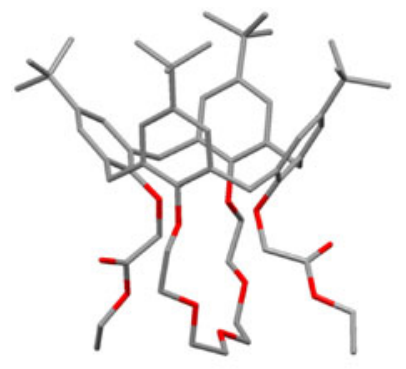

(a)

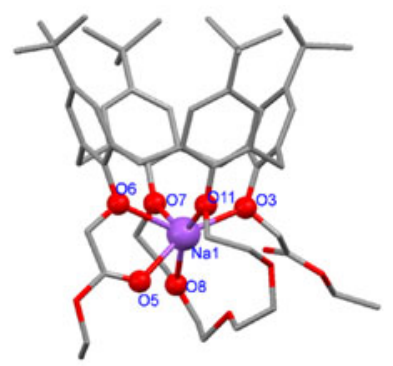

(b)

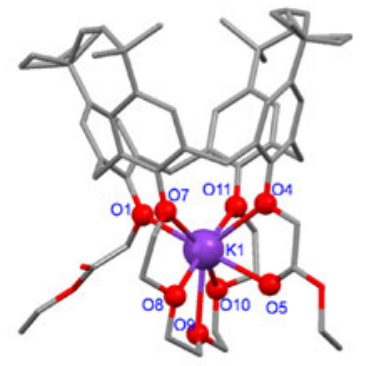

(c)

Figure 2. Crystal structures of the receptors $\mathbf{3 d}(\mathbf{a})$ and its $\mathrm{Na}^{+}(\mathbf{b})$ and $\mathrm{K}^{+}(\mathbf{c})$ complexes.

\section{Effect of steric crowding on ion selectivity for calix-crown hybrid ionophores}

A number of calix[4]arene-azacrown with variation in ring size and bulky substituents at the upper and lower rims were synthesized to investigate the effect of steric crowding towards ion selectivity. ${ }^{8}$ The substituent, $p$-toluene sulphonamide is attached with the nitrogen atom(s) of the crown moiety and tert-butyl/hydrogen is incorporated in the upper rim $(\mathbf{4 a} \mathbf{a}-\mathbf{4 d})$. All of these compounds were characterized crystallographically. Interaction of these ionophores with a large number of metal ions $\left(\mathrm{Li}^{+}, \mathrm{Na}^{+}, \mathrm{K}^{+}, \mathrm{Rb}^{+}, \mathrm{Cs}^{+}, \mathrm{Mg}^{2+}, \mathrm{Ca}^{2+}, \mathrm{Sr}^{2+}\right.$, $\mathrm{Ba}^{2+}, \mathrm{Zn}^{2+}, \mathrm{Cd}^{2+}, \mathrm{Hg}^{2+}$ and $\mathrm{Pb}^{2+}$ ) has been investigated by NMR study. The ionophore without tert-butyl at upper rim (4a) showed selectivity towards both $\mathrm{Na}^{+}$ and $\mathrm{K}^{+}$, ionophore with larger crown ring and without tert-butyl at upper rim (4b) exhibited complexation with $\mathrm{K}^{+}, \mathrm{Rb}^{+}, \mathrm{Ba}^{2+}$ and weak interaction with $\mathrm{Na}^{+}$,

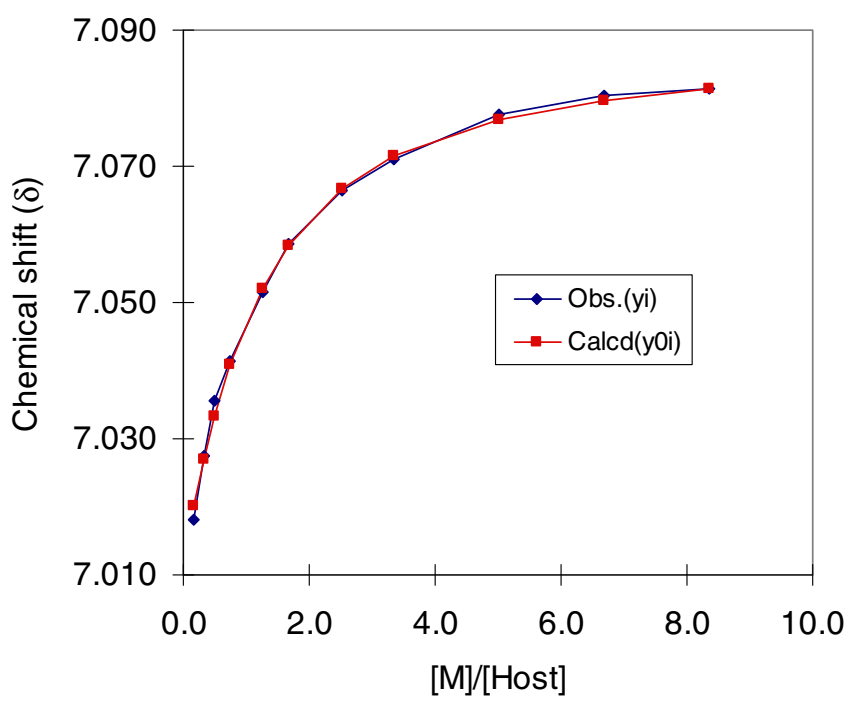

Figure 3. The non-linear least square fit from ${ }^{1} \mathrm{H}$ NMR titration data for the determination of binding constant for $\mathbf{4 b}$ with $\mathrm{Ba}^{2+}$ in $\mathrm{CD}_{3} \mathrm{CN}-\mathrm{CDCl}_{3}(3: 1)$ at room temperature. whereas ionophore of same ring size as $\mathbf{4 a}$ and with tert-butyl at upper rim (4c) exhibits selectivity towards only $\mathrm{Na}^{+}$and ionophore with three tosyl substituents at the lower rim (4d) exhibited no complexation with any metal ion. The steric crowding has nicely controlled the selectivity. For the determination of binding constants, NMR titrations were carried out with the strongly interacting metal ions. Interestingly, in a few cases $\left(\mathrm{K}^{+}\right.$for $\mathbf{4 a}$, and $\mathrm{Na}^{+}$for $\mathbf{4 c}$ ), upon addition of increasing concentration of metal ions new peaks were observed with gradual disappearance of the original signals whereas in other cases, gradual shift of certain signals were noted with the addition of metal ions. This is because of the compatibility of the metal ion in the cavity, if metal ion fits appropriately then new peak appears for the complex and if the metal ion does not fit properly, then bond dissociation and association take place simultaneously resulting in gradual change in chemical shifts of certain signals. Binding constants for the latter situation were calculated using the program developed by Hirose ${ }^{13}$ (figure 3) and for development of new peaks direct methods were used for calculation and all the data are given in table 2. The binding constant $\left(K_{s}\right)$ values suggest that steric crowding and size-matching factors have profound influence on ion-selectivity. The difference in the selectivity with

Table 2. Binding constants $\left(K_{S}\right)$ for the ionophores $\mathbf{4 a}-\mathbf{4 c}$, determined by NMR titration.

\begin{tabular}{lcc}
\hline Ionophore & Metal ion & $\begin{array}{c}\text { Binding constant } \\
\left(K_{s} / \mathrm{M}^{-1}\right)\end{array}$ \\
\hline 4a & $\mathrm{Na}^{+}$ & $3.10 \times 10^{3}$ \\
& $\mathrm{~K}^{+}$ & $4.17 \times 10^{3}$ \\
4b & $\mathrm{Na}^{+}$ & $6.00 \times 10$ \\
& $\mathrm{~K}^{+}$ & $4.19 \times 10^{3}$ \\
& $\mathrm{Rb}^{+}$ & $4.55 \times 10^{4}$ \\
& $\mathrm{Ba}^{2+}$ & $3.35 \times 10^{2}$ \\
4c & $\mathrm{Na}^{+}$ & $2.05 \times 10^{3}$ \\
\hline
\end{tabular}




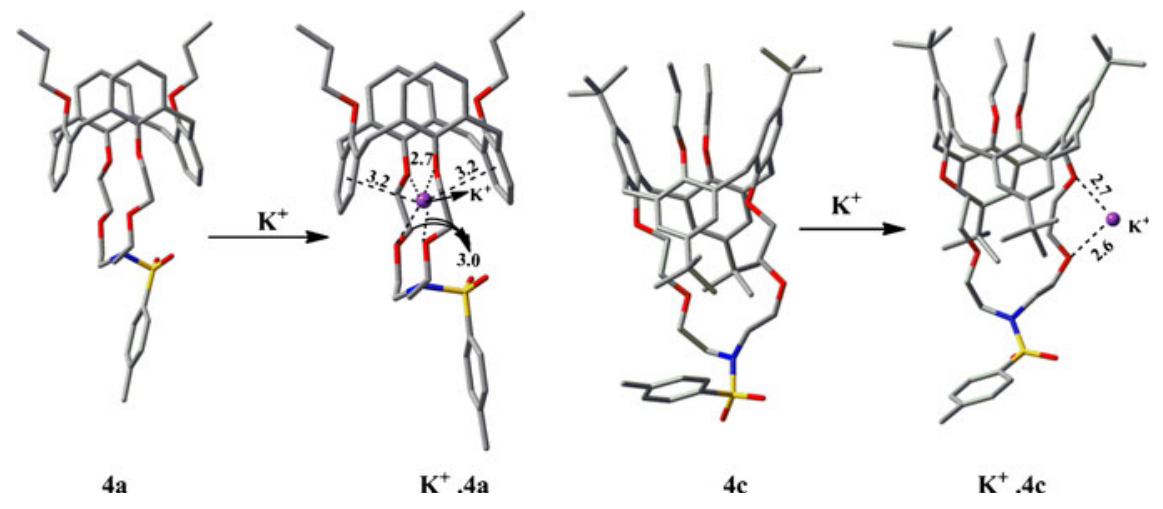

Figure 4. DFT calculated GGA/PW91/DNP level for the parent structure and the lowest energy conformations for $\mathbf{4 a}$ and $\mathbf{4 c}$ with $\mathrm{K}^{+}$(in acetonitrile). The distances are in $\AA$ (grey: carbon, red: oxygen, blue: nitrogen, yellow: sulphur).

various cations, as observed experimentally, was also predicted by molecular modelling studies employing (MMFF94) force field and DFT calculations. The difference in the selectivity with $\mathrm{K}^{+}$for $\mathbf{4 a}$ and $\mathbf{4 c}$ was predicted by molecular modelling studies as shown in figure 4.

\section{Fluorescent receptors using $\left[\operatorname{Ru}(b p y)_{3}\right]^{2+}$ as fluorophor and calix-crown hybrid molecule as ionophore}

For monitoring ion-recognition event, fluorescent technique has been widely used because of some advantages in terms of sensitivity, selectivity, response time and in situ monitoring. This method of detection requires fluoroionophore, which can be developed by covalent linking of a luminescent molecule with the ionophore and the photophysical property of the fluorophore perturbs during the recognition process producing changes in luminescent emission. ${ }^{14} \mathrm{Ru}$ (II)-bipyridine moiety, which exhibits strong absorption band in the near UVvis region and an intense emission band in the visible region, can be used as luminescent fragment to develop fluoroionophore. $\mathrm{Ru}(\mathrm{II})$-bipyridine as fluorophore possess some advantages over the organic luminescent molecules in the event of ion recognition process, beside change in fluorescence, it may also exhibit electrogenerated chemiluminesence (ECL) and change in the oxidation potential of metal ion. ${ }^{15} \mathrm{~A}$ few recent reports indicate that response of complex formation also depends on methods of detection, the same receptor shows selectivity towards $\mathrm{Cu}^{2+}$ in $\mathrm{UV}$-vis, $\mathrm{Pb}^{2+}$ and $\mathrm{Cu}^{2+}$ in fluorescence, $\mathrm{Hg}^{2+}$ in electrogenerated chemiluminesence (ECL) and $\mathrm{Pb}^{2+}$ in electrochemical study. ${ }^{15 b, 15 c}$

To develop such fluoroionophores, a series of molecular receptors containing $\mathrm{Ru}(\mathrm{II})$ bipyridine moie- ty as fluorophore and calix[4]arene-azacrown hybrid molecule as ionophore were synthesized. ${ }^{6}$ These receptors (5-8) exhibit strong ${ }^{3}$ MLCT luminescence band in the range $613-618 \mathrm{~nm}$. Cation-binding property of these fluoroionophores were investigated with the metal ions $\mathrm{Na}^{+}, \mathrm{K}^{+}, \mathrm{Mg}^{2+}, \mathrm{Ca}^{2+}, \mathrm{Cs}^{+}, \mathrm{Zn}^{2+}, \mathrm{Cd}^{2+}, \mathrm{Hg}^{2+}$ and $\mathrm{Pb}^{2+}$ and the recognition event was monitored by

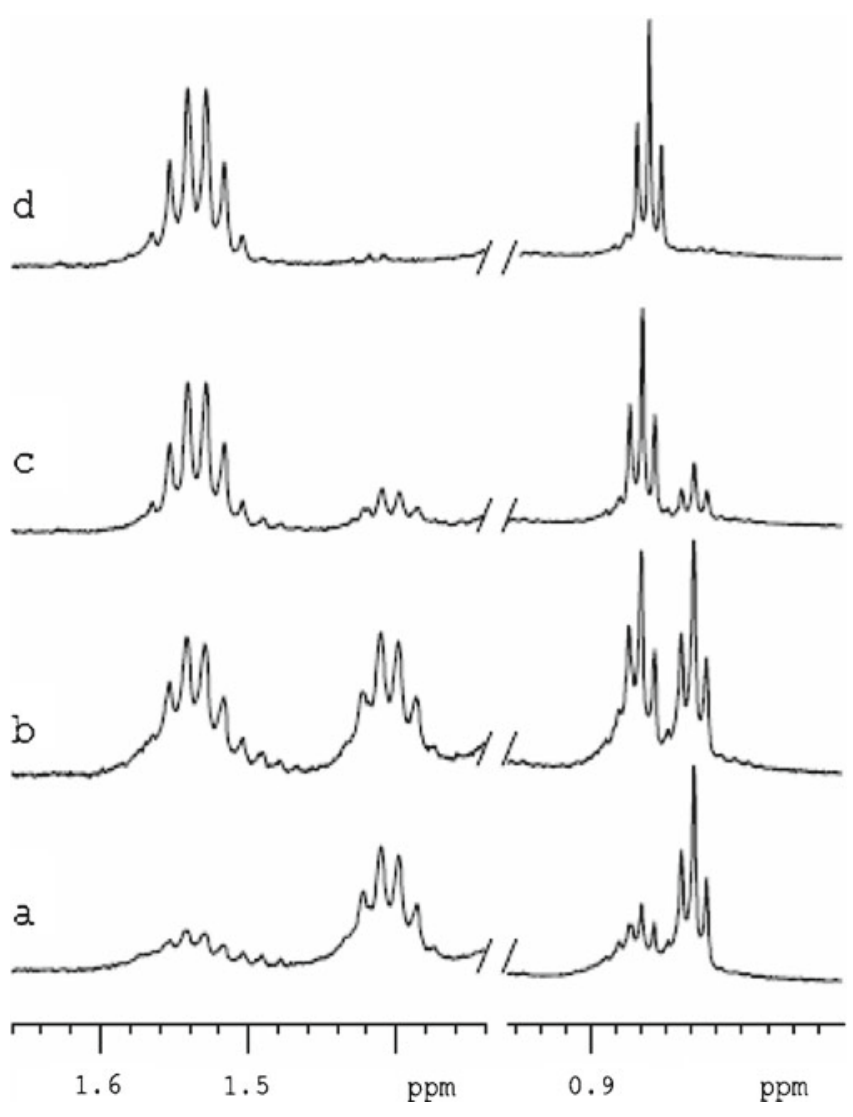

Figure 5. Selected portion of the ${ }^{1} \mathrm{H}$ NMR spectral change for $\mathbf{5}$ upon addition of the increasing concentration of $\mathrm{KClO}_{4}$, new peaks are growing with disappearance of the peaks of original complex. 
luminescence, ${ }^{1} \mathrm{H}$ NMR, redox potential and UV-vis absorption studies. In luminescence, formation of metal complex is indicated by significant change in emission intensity (figure S1). Luminescence study suggested complexation of all four receptors $(\mathbf{5}-\mathbf{8})$ with $\mathrm{Zn}^{2+}, \mathrm{Cd}^{2+}$ and $\mathrm{Hg}^{2+}$ and for $\mathbf{6}$ and $\mathbf{8}$ also with $\mathrm{Pb}^{2+}$. For alkali and alkaline earth metal ions the recognition event was also monitored by ${ }^{1} \mathrm{H}$ NMR spectroscopy and it exhibited interactions of $\mathrm{Na}^{+}$and $\mathrm{K}^{+}$with $\mathbf{5}$ and $\mathbf{8}$, $\mathrm{K}^{+}$and $\mathrm{Cs}^{+}$with $\mathbf{6}$, and $\mathrm{K}^{+}$with 7 (figure 5). Selective electrochemical response towards interaction of certain metal ions was also noted by the shift of the oxidation potentials of the $\mathrm{Ru}(\mathrm{II})$ measured in the presence of guest metal ions (figure 6). These metal ions are $\mathrm{Na}^{+}, \mathrm{Hg}^{2+}$ and $\mathrm{Pb}^{2+}$ for $\mathbf{5}$ and $\mathbf{6}$ but not for $\mathbf{7}$ and $\mathbf{8}$. The binding constants (except 8) and stoichiometries
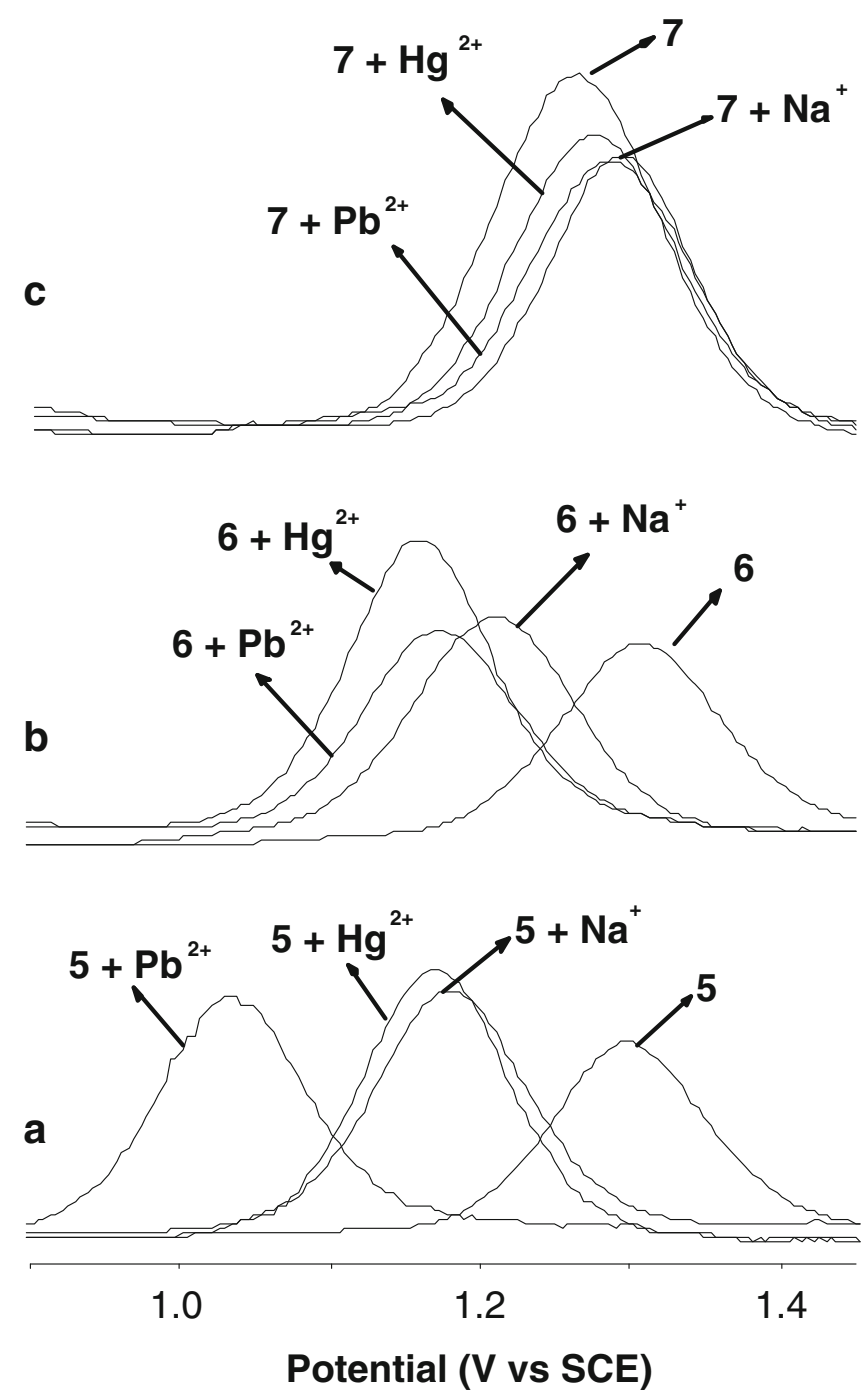

Figure 6. Oxidation potential (DPV) of Ru(II) for 5 (a), 6 (b) and 7 (c), and the same in the presence of $\mathrm{Na}^{+}, \mathrm{Hg}^{2+}$ and $\mathrm{Pb}^{2+}$ (50 equiv) in acetonitrile.
Table 3. Binding constant $\left(K_{s}\right)$ for complex formation with metal ions for the $\mathrm{Ru}(\mathrm{II})$ receptors.

\begin{tabular}{|c|c|c|c|}
\hline \multirow[b]{2}{*}{ Complex } & \multirow[b]{2}{*}{$\begin{array}{l}\text { Metal } \\
\text { ion }\end{array}$} & \multicolumn{2}{|c|}{$\begin{array}{l}\text { Binding constants } \\
\qquad\left(K_{s}, \mathrm{M}^{-1}\right)\end{array}$} \\
\hline & & $\begin{array}{c}\text { From fluorescence } \\
\text { titration }\end{array}$ & $\begin{array}{l}\text { From NMR } \\
\text { titration }\end{array}$ \\
\hline \multirow[t]{5}{*}{5} & $\mathrm{Zn}^{2+}$ & $1.46 \pm 0.44 \times 10^{5}$ & - \\
\hline & $\mathrm{Cd}^{2+}$ & $2.36 \pm 0.41 \times 10^{4}$ & - \\
\hline & $\mathrm{Hg}^{2+}$ & $3.44 \pm 0.33 \times 10^{4}$ & - \\
\hline & $\mathrm{Na}^{+}$ & - & $5.43 \pm 0.18 \times 10^{2}$ \\
\hline & $\mathrm{K}^{+1}$ & - & $6.81 \pm 0.44 \times 10^{3}$ \\
\hline \multirow[t]{6}{*}{6} & $\mathrm{Zn}^{2+}$ & $2.81 \pm 0.52 \times 10^{4}$ & - \\
\hline & $\mathrm{Cd}^{2+}$ & $6.27 \pm 0.42 \times 10^{3}$ & - \\
\hline & $\mathrm{Hg}^{2+}$ & $2.53 \pm 0.36 \times 10^{5}$ & - \\
\hline & $\mathrm{Pb}^{2+}$ & $2.00 \pm 0.33 \times 10^{4}$ & - \\
\hline & $\mathrm{K}^{+}$ & - & $1.45 \pm 0.42 \times 10^{3}$ \\
\hline & $\mathrm{Cs}^{+}$ & - & $1.64 \pm 0.32 \times 10^{3}$ \\
\hline \multirow[t]{4}{*}{7} & $\mathrm{Zn}^{2+}$ & $6.93 \pm 0.54 \times 10^{4}$ & - \\
\hline & $\mathrm{Cd}^{2+}$ & $9.65 \pm 0.48 \times 10^{3}$ & - \\
\hline & $\mathrm{Hg}^{2+}$ & $1.34 \pm 0.38 \times 10^{5}$ & - \\
\hline & $\mathrm{Pb}^{2+}$ & $1.61 \pm 0.47 \times 10^{4}$ & - \\
\hline
\end{tabular}

of the complexes were determined from the luminescence and NMR titration data (table 3 ). The $K_{s}$ values are ranging from $2.53 \times 10^{5}$ to $1.45 \times 10^{3} \mathrm{M}^{-1}$, the ionic size, conformation and effective cavity size of the ionophore, coordinating ability of cations with $\mathrm{O}_{4} \mathrm{~N}$ donor set, and enthalpy of hydration/solvation of the cations are the primary factors to influence binding constants. The most important observation is that a single method of detection is not conclusive to determine the complexing ability of a particular receptor. A sensor molecule having single type of receptor site may act as a multi-ion analyser by using an array of detection methods. For multi-ion sensing, the receptor should exhibit conformational preferences depending on the detection method and in this regard flexible ionophores with multi donor atoms are more suitable.

\section{Fluorescent molecular sensors with excimer emission and effect of solvent in ion selectivity}

In designing of fluorescent sensors, an interesting approach is to attach two aromatic fluorophores in proximity so that they are close enough (within van der Waals contact) to make interaction such as $\pi-\pi$ stacking. Under this condition, electronic excitation of one ring can cause an enhanced interaction with its neighbour, leading to what is termed as excited-state dimer or excimer. ${ }^{1 e, 16}$ This excimer typically provides a broad fluorescence band with the maxima at lower energy compared to emission from monomer and this 
band can be used to read out the molecular recognition process more conveniently. In general, highly $\pi$-delocalized planar systems such as pyrene and naphthyl moieties have been used for this purpose, they exhibited intramolecular excimer due to strong $\pi-\pi$ interaction between two fluorophore units and this excimer emission perturbed in the presence of guest ions. ${ }^{17}$

With a view to develop this class of fluoroionophores, molecular sensors incorporating calix[4]arene derivatives in cone and 1,3-alternate conformation as ionophore and two pyrene moieties at close proximity as fluorophore were synthesized $(\mathbf{9}, \mathbf{1 0}) .^{9}$ They exhibit strong excimer emission around $515 \mathrm{~nm}$ due to face to face $\pi-\pi$ stacking of the pyrene moieties and this band is used to monitor the interaction of metal ions with the ionophores. Ion-binding study of these fluoroionophore has been investigated in acetonitrilechloroform and THF- $\mathrm{H}_{2} \mathrm{O}$ with a wide range of cations $\left(\mathrm{Li}^{+}, \mathrm{Na}^{+}, \mathrm{K}^{+}, \mathrm{Cs}^{+}, \mathrm{Mg}^{2+}, \mathrm{Ca}^{2+}, \mathrm{Sr}^{2+}, \mathrm{Ba}^{2+}, \mathrm{Zn}^{2+}\right.$, $\mathrm{Cd}^{2+}, \mathrm{Hg}^{2+}, \mathrm{Cu}^{2+}, \mathrm{Ni}^{2+}$ and $\left.\mathrm{Pb}^{2+}\right)$ and the recognition process is monitored by luminescence and UV-vis spectroscopy. In acetonitrile-chloroform, the intensity of the excimer emission significantly decreased in the presence of $\mathrm{Hg}^{2+}, \mathrm{Pb}^{2+}, \mathrm{Cu}^{2+}$ and $\mathrm{Ni}^{2+}$ due to break down of the $\pi-\pi$ stacking as the pyrene moieties separated from each other because of complex formation (11) (figure $\mathrm{S} 2$ ). Interestingly, in THF- $\mathrm{H}_{2} \mathrm{O}$ they exhibited complex formation selectivity only with $\mathrm{Cu}^{2+}$ (figure 7). Dramatic change in selectivity in $\mathrm{THF}-\mathrm{H}_{2} \mathrm{O}$ is probably due to hydration of metal ion, the effective size of the first hydration shell of metal ion with six water molecules played crucial role in determining the selectivity. The size of the hydrated shell of the tetra hydrated $\mathrm{Cu}^{2+}$

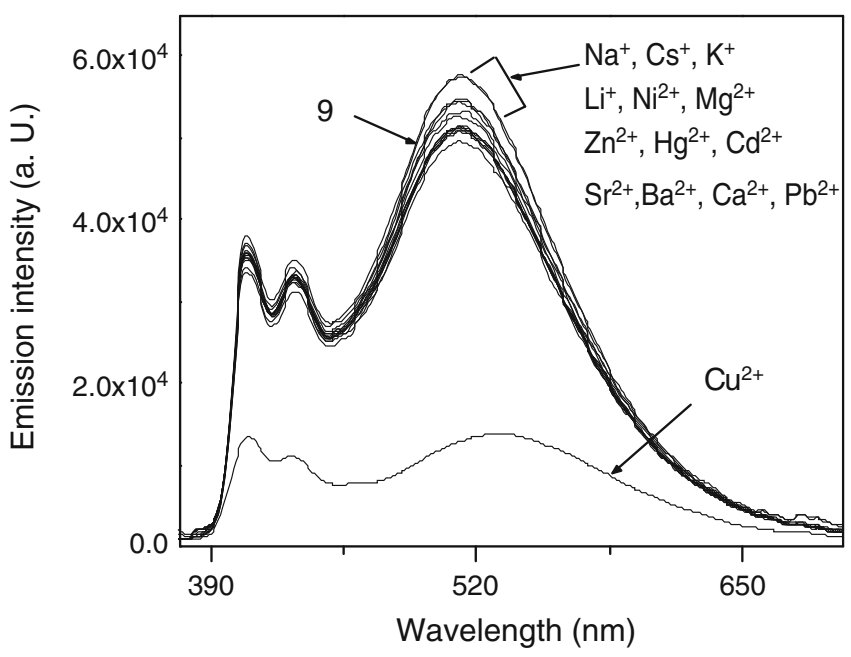

Figure 7. Luminescence spectra of $9\left(1 \times 10^{-6} \mathrm{M}\right)$ recorded in $\mathrm{THF}-\mathrm{H}_{2} \mathrm{O}(4: 1)$ in the presence of various cations (100 equiv).
Table 4. Binding constant $\left(K_{s}\right)$ with metal ions for compounds 9 and $\mathbf{1 0}$ in $\mathrm{CH}_{3} \mathrm{CN}-\mathrm{CHCl}_{3}$ and $\mathrm{THF}-\mathrm{H}_{2} \mathrm{O}$.

\begin{tabular}{|c|c|c|c|}
\hline Compound & Solvent & $\begin{array}{c}\text { Metal } \\
\text { ion }\end{array}$ & $\begin{array}{l}\text { Binding } \\
\text { constant } \\
\left(K_{S}\right) \mathrm{M}^{-1}\end{array}$ \\
\hline \multirow[t]{5}{*}{9} & $\mathrm{CH}_{3} \mathrm{CN}-\mathrm{CHCl}_{3}(9: 1)$ & $\mathrm{Cu}^{2+}$ & $2.88 \times 10^{5}$ \\
\hline & & $\mathrm{Hg}^{2+}$ & $5.4 \times 10^{4}$ \\
\hline & & $\mathrm{Pb}^{2+}$ & $6.0 \times 10^{4}$ \\
\hline & & $\mathrm{Ni}^{2+}$ & $5.6 \times 10^{3}$ \\
\hline & $\mathrm{THF}-\mathrm{H}_{2} \mathrm{O}(4: 1)$ & $\mathrm{Cu}^{2+}$ & $3.98 \times 10^{5}$ \\
\hline \multirow[t]{6}{*}{10} & $\mathrm{CH}_{3} \mathrm{CN}-\mathrm{CHCl}_{3}(9: 1)$ & $\mathrm{Cu}^{2+}$ & $3.3 \times 10^{4}$ \\
\hline & & $\mathrm{Hg}^{2+}$ & $1.8 \times 10^{4}$ \\
\hline & & $\mathrm{Pb}^{2+}$ & $4.6 \times 10^{4}$ \\
\hline & & $\mathrm{Ni}^{2+}$ & $4.9 \times 10^{4}$ \\
\hline & & $\mathrm{Na}^{+}$ & $1.8 \times 10^{3}$ \\
\hline & $\mathrm{THF}-\mathrm{H}_{2} \mathrm{O}(4: 1)$ & $\mathrm{Cu}^{2+}$ & $4.25 \times 10^{4}$ \\
\hline
\end{tabular}

ion probably fits to enter the ionophore cavity formed by stacked pyrene moieties to form complex. The large size of the hydrated shell of the bigger cations with six water molecules could not enter the cavity to form complex. Binding constants for the fluoroionophores 9 and 10 with strongly interacting ions were determined using emission titration data (figure S3) and the values are in the range $1.8 \times 10^{3}-3.98 \times 10^{5} \mathrm{M}^{-1}$ (table 4). Analysis of the data showed that for 9 in acetonitrilechloroform, the binding constant for $\mathrm{Cu}^{2+}$ is significantly higher than that of $\mathrm{Hg}^{2+}$ and $\mathrm{Pb}^{2+}$ and it is lowest for $\mathrm{Ni}^{2+}$. The $\mathrm{Cu}^{2+}$ ion is harder acid compared to $\mathrm{Hg}^{2+}$ and $\mathrm{Pb}^{2+}$ and prefers to bind oxygen donor atoms, which promotes formation of strong complex with four oxygen donor atoms $(\mathrm{C}=\mathrm{O}$ and deprotonated $\mathrm{OH})$ as shown in 11. For compound 10, the binding constants with all the four cations, $\mathrm{Hg}^{2+}, \mathrm{Pb}^{2+}, \mathrm{Cu}^{2+}$ and $\mathrm{Ni}^{2+}$ are similar, $\mathrm{Cu}^{2+}$ has lost preferential binding as there is no $\mathrm{OH}$ and complexation took place probably with deprotonation of less acidic NH protons and with two substituted phenolic oxygen atoms (figure S4).

\section{Cation-induced fluorescent excimer emission in molecular sensors bearing quinoline as fluoregenic unit}

In the above section, we have discussed about excimer emission formed by closely spaced pyrene moieties due to strong $\pi-\pi$ interaction. A fluoroionophore containing thiacalix[4]arene as ionophore and naphthyl groups as fluoregenic units has been recently reported, which exhibits formation of excimer in the presence of $\mathrm{F}^{-} .{ }^{18}$ The structure of the quinoline moiety is similar to that of naphthyl unit, however only a few studies have been reported using quinoline as fluorogenic unit 


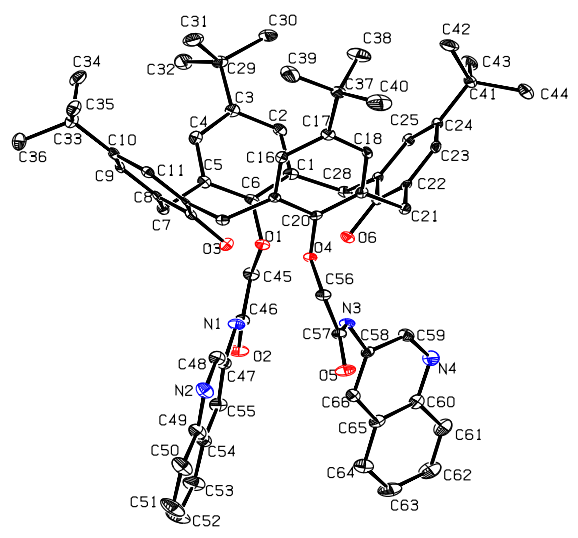

(a)

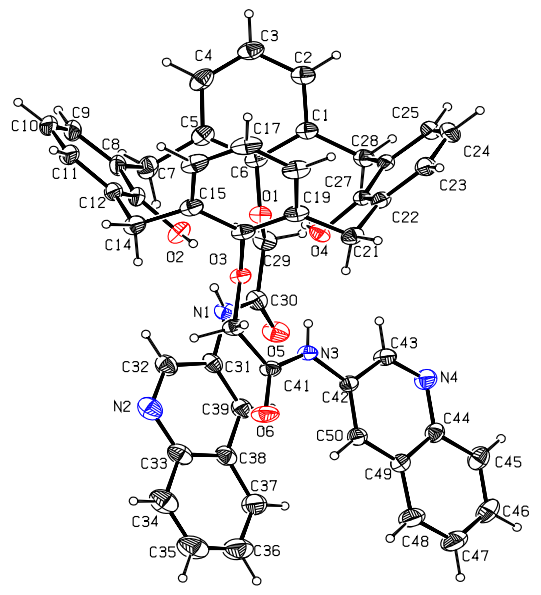

(b)

Figure 8. ORTEP diagram of $\mathbf{1 2}$ (a) and $\mathbf{1 3}$ (b) with atom numbering scheme (30\% probability factor for the thermal ellipsoids), lattice solvent molecules are omitted for clarity. The nitrogen containing rings in both the structures make an offset $\pi-\pi$ stacking interaction and also $\mathrm{C}-\mathrm{H} . . . \pi$ interactions.

in calixarene based fluoroionophores but no excimer emission has been reported. Quinoline-based receptors of non-macrocyclic ligands, however have been reported, which exhibited intra- and intermolecular excimer emission upon hydrogen bond mediated complexation with organic acids and phosphate anion. ${ }^{19}$

With the aim to develop calixarene-based chemosensors with excimer emission, we have synthesised a family of calixarene derivatives incorporating quinoline moiety as fluorophore with the expectation that the quinoline moieties may exhibit excimer emission, as observed for pyrene (12-14). All of these compounds

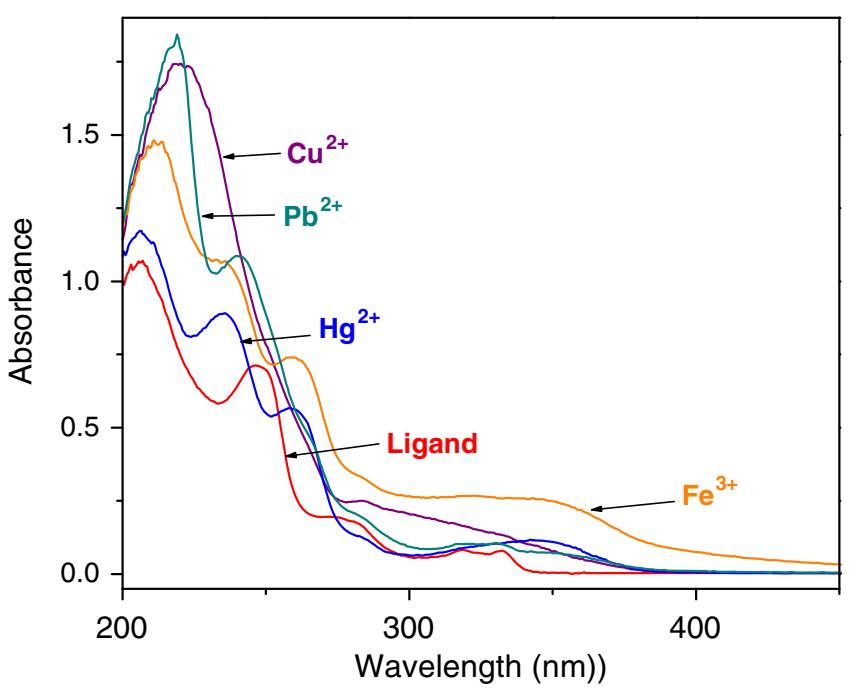

Figure 9. UV-vis spectral changes for $\mathbf{1 3}$ upon addition of excess amount of $\mathrm{Hg}^{2+}, \mathrm{Pb}^{2+}, \mathrm{Fe}^{3+}$ and $\mathrm{Cu}^{2+}$ as perchlorate salts in acetonitrile. were crystallographically characterized and at least two of them exhibited quinoline moieties in a favourable position to make interaction to exhibit excimer emission (figure 8); however none of these fluoroionophore showed any such emission band. The ion-binding property of these fluoroionophores has been investigated with a large number of cations, among which $\mathrm{Hg}^{2+}$, $\mathrm{Pb}^{2+}, \mathrm{Fe}^{3+}$ and $\mathrm{Cu}^{2+}$ exhibited strong complexation with all of the ionophores, as evident from luminescence and UV-vis spectroscopy (figure 9). Interestingly, upon complexation with these metal ions a broad new band at lower energy $(\sim 410 \mathrm{~nm})$ is

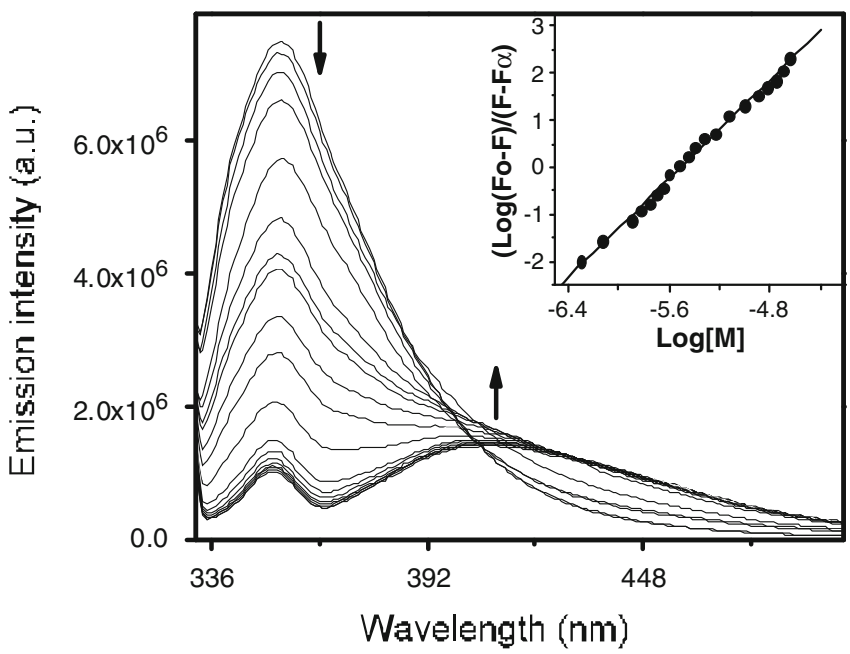

Figure 10. Emission spectral changes for $12(2.5 \times$ $\left.10^{-6} \mathrm{M}\right)$ upon addition of increasing amount of $\mathrm{Cu}\left(\mathrm{ClO}_{4}\right)_{2}$. Excitation wavelength: $318 \mathrm{~nm}$. Inset: linear regression fit (double-logarithmic plot) of the titration data as a function of concentration of metal ion. 
Table 5. Binding constants $\left(K_{s}\right)$ for complex formation with metal ions for 12-14.

\begin{tabular}{lccc}
\hline \multirow{2}{*}{ Ionophore } & \multicolumn{2}{c}{ Binding constant $\left(K_{s} / \mathrm{M}^{-1}\right)$} \\
\cline { 3 - 4 } & $\begin{array}{c}\text { Metal } \\
\text { ion }\end{array}$ & $\begin{array}{c}\text { Emission } \\
\text { titration }\end{array}$ & $\begin{array}{c}\text { UV-vis/NMR } \\
\text { titration }\end{array}$ \\
\hline $\mathbf{1 2}$ & $\mathrm{Hg}^{2+}$ & $6.43 \times 10^{4}$ & $5.93 \times 10^{4}$ \\
& $\mathrm{~Pb}^{2+}$ & $3.01 \times 10^{4}$ & $4.91 \times 10^{4}$ \\
& $\mathrm{Fe}^{3+}$ & $1.23 \times 10^{6}$ & $5.34 \times 10^{5}$ \\
& $\mathrm{Cu}^{2+}$ & $2.21 \times 10^{4}$ & $2.38 \times 10^{4}$ \\
& $\mathrm{Hg}^{2+}$ & $1.32 \times 10^{5}$ & $1.02 \times 10^{5}$ \\
& $\mathrm{~Pb}^{2+}$ & $1.20 \times 10^{5}$ & $1.11 \times 10^{5}$ \\
& $\mathrm{Fe}^{3+}$ & $2.07 \times 10^{5}$ & $1.20 \times 10^{5}$ \\
& $\mathrm{Fe}^{2+}$ & $8.22 \times 10^{3}$ & $5.53 \times 10^{3}$ \\
& $\mathrm{Cu}^{2+}$ & $1.05 \times 10^{5}$ & $0.95 \times 10^{5}$ \\
& $\mathrm{Hg}^{2+}$ & $4.05 \times 10^{5}$ & $1.34 \times 10^{5}$ \\
& $\mathrm{~Pb}^{2+}$ & $4.89 \times 10^{5}$ & $1.97 \times 10^{5}$ \\
& $\mathrm{Fe}^{3+}$ & $1.17 \times 10^{5}$ & $1.02 \times 10^{5}$ \\
& $\mathrm{Cu}^{2+}$ & $4.30 \times 10^{4}$ & $2.52 \times 10^{4}$ \\
\hline
\end{tabular}

observed, which is attributed to excimer emission for all the three fluoroionophores (figure 10 and figure S5). Binding constants for 12-14 with strongly interacting ions were determined using emission and absorption titration data following the literature procedure. The $K_{s}$ values are in the range $5.5 \times 10^{3}-1.2 \times 10^{6} \mathrm{M}^{-1}$ (table 5). Analysis of the data showed that for 12 and 13, the $K_{s}$ values follow the order $\mathrm{Cu}^{2+}<\mathrm{Pb}^{2+} \sim \mathrm{Hg}^{2+}<\mathrm{Fe}^{3+}$, the highest value for $\mathrm{Fe}^{3+}$ is probably due to its highest positive charge. To examine it, the $K_{s}$ value for $\mathrm{Fe}^{2+}$ with the ionophore $\mathbf{1 3}$ was determined using both emission and UV/vis titration methods and the values are significantly low compared to that obtained for $\mathrm{Fe}^{3+}$. It indicates that in addition to the size matching factor, ionic charge also play important role to form strong complex. For 14, the $K_{s}$ values follow the similar order as noted for $\mathbf{1 2}$ and $\mathbf{1 3}$, except for $\mathrm{Fe}^{3+}$, the difference is probably due to lack of $\mathrm{OH}$ group in the lower rim of the calixarene moiety, as $\mathrm{Fe}^{3+}$ preferes to bind with oxygen atom.

To find out the possible reason for excimer emission after complexation with metal ions, we were interested to investigate the positions of the quinoline moieties in the complexes. Our attempt to grow single crystals for structure detrmination was not successful, however it motivated us to take up molecular modelling (a)

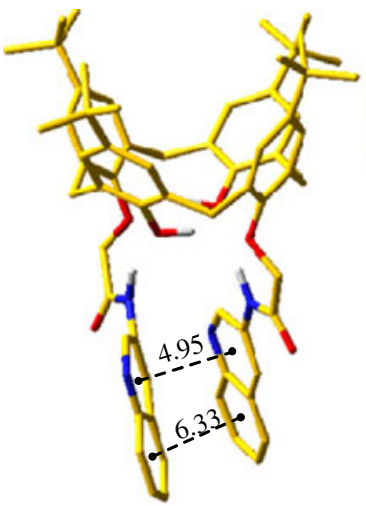

12

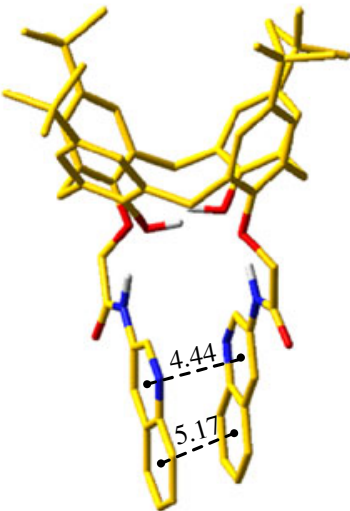

12

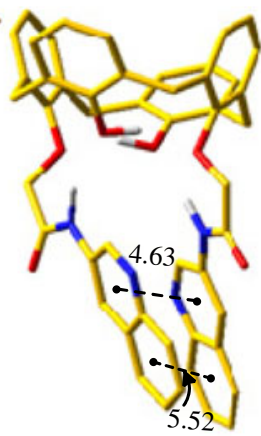

13

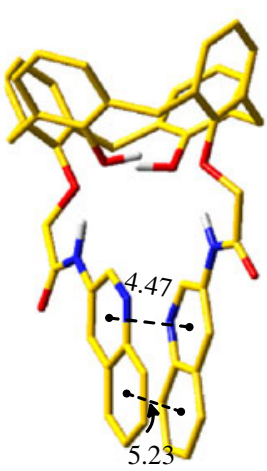

13

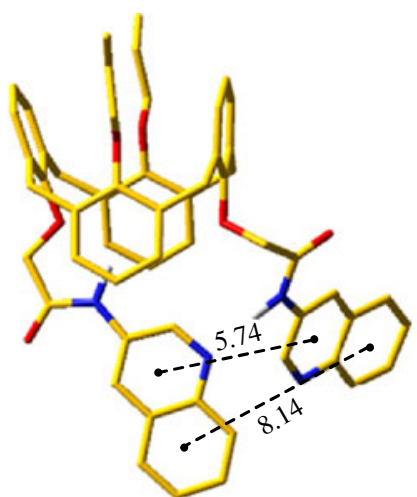

14

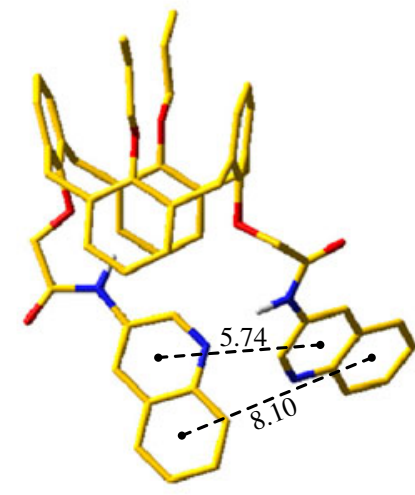

14

Figure 11. Geometries of compound 12-14 (a) crystal structure, (b) calculated lowest energy conformations in molecular mechanics (MMFF94) force field using Monte Carlo search method in the gas phase (distances are in $\AA$ ) (yellow = carbon, red $=$ oxygen; blue $=$ nitrogen; white $=$ hydrogen $)$. 
study to examine the mode of interaction of the metal ions with the ionophores and their relative influence on the excimer emission. We have employed molecular mechanics (MMFF94) force field using Monte Carlo search method to examine the different conformations of 12-14 calix ionophores. The lowest energy conformer of parent receptors in the gas phase shows a good resemblance with the crystal structures (figure 11). The arrangement of quinoline rings and their relative distances in the calculated geometries are similar to that of the observed crystal structures. The calculated gas phase geometries of ionophores 12-14 were considered for the ion binding studies. The calculations were performed with the lowest energy conformers placing the metal ions $\left(\mathrm{Hg}^{2+}, \mathrm{Pb}^{2+}, \mathrm{Fe}^{3+}\right.$ and $\mathrm{Cu}^{2+}$ ) at the centroid of the upper rims and in the centre of the cavity of receptors in lower rims in each case. All ion complexed ionophores were fully optimized at (DFT) GGA/PW91/DND level of theory and the DFT calculated results yielded the same complexed geometries irrespective of the placement of ions in the upper and lower rims of calix- moieties. Interestingly, the calculated results showed larger distance between the quinoline rings upon complexation of metal ions compared to parent ionophores. This observation suggested that the excimer emission might arise due to the change in the frontier molecular orbital transitions. ${ }^{3 a}$ Further calculations were performed on the frontier molecular orbitals of 12-14 and their metal ion complexes at M05-2X/6-31G* level and LANL2DZ basis set on the basis of two cyrstal structures of $\mathrm{Hg}^{2+}$ complexes of 13 and 14 with $\mathrm{Cl}^{-}$anion. The detail of calculated results suggest that the frontier molecular orbital energy gap reduces upon complexation with metal ions, which presumably responsible for the excimer emission in this case.

\section{Calixarene based fluoroionophores for the detection of anions}

In designing of anion receptors, various non-covalent interactions, such as hydrogen-bonding, electrostatic, hydrophobicity, are mainly considered to make interaction between binding sites and anions. ${ }^{20}$ The receptors 10-14, described above, contain amide group at the lower rim, therefore they may act as potential anion sensor. To investigate this possibility, all of these receptors were treated with a number of anions $\left(\mathrm{F}^{-}, \mathrm{Cl}^{-}, \mathrm{Br}^{-}\right.$, $\mathrm{I}^{-}, \mathrm{H}_{2} \mathrm{PO}_{4}^{-}, \mathrm{ClO}_{4}^{-}, \mathrm{NO}_{3}^{-}, \mathrm{BF}_{4}^{-}, \mathrm{CH}_{3} \mathrm{COO}^{-}$, and $\mathrm{HSO}_{4}^{-}$) and the recognition event was monitored by fluorescence, UV-vis and NMR spectroscopy. In the fluorescence spectra, substantial quenching in emission

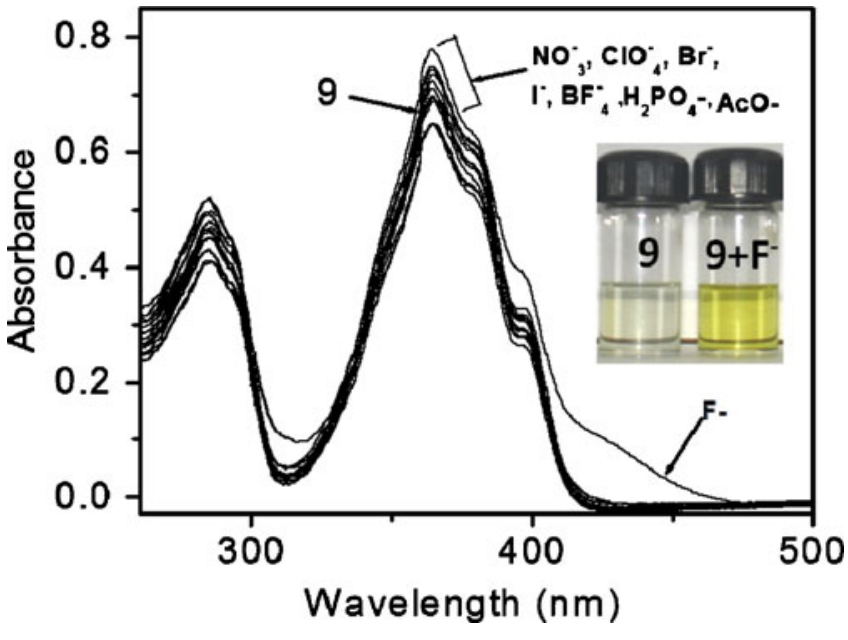

Figure 12. UV-vis spectral change for $9\left(1.83 \times 10^{-5} \mathrm{M}\right)$ recorded in acetonitrile-chloroform (9:1) in the presence of various anions (100 equiv). Inset: colour change of $\mathbf{1 0}$ upon addition of $\mathrm{F}^{-}$(TBAF).

intensity was noted for $\mathrm{F}^{-}$for all of these receptors, except 14, indicating strong complexation with $\mathrm{F}^{-}$. The anion $\mathrm{HSO}_{4}^{-}$also exhibited complexation with 12 and 13. Binding constant for anions were also determined from emission titration data. In the UV-vis spectra, $\mathrm{F}^{-}$ exhibited significant change upon complexation, the change was prominent for $\mathbf{1 0}$ with a distinct colour change (figure 12). The new band observed around $430 \mathrm{~nm}$ with the colour change is due to intramolecular charge transfer (ICT) because of the deprotonation of $\mathrm{OH}$. The involvement of $\mathrm{NH}$ of the amide moiety and $\mathrm{OH}$ of the calix moiety in complexation with $\mathrm{F}^{-}$ and $\mathrm{HSO}_{4}^{-}$, respectively is evident from ${ }^{1} \mathrm{H}$ NMR study (figure 13). A substantial change in chemical shifts of the $\mathrm{OH}$ and $\mathrm{NH}$ proton and disappearance of signals in

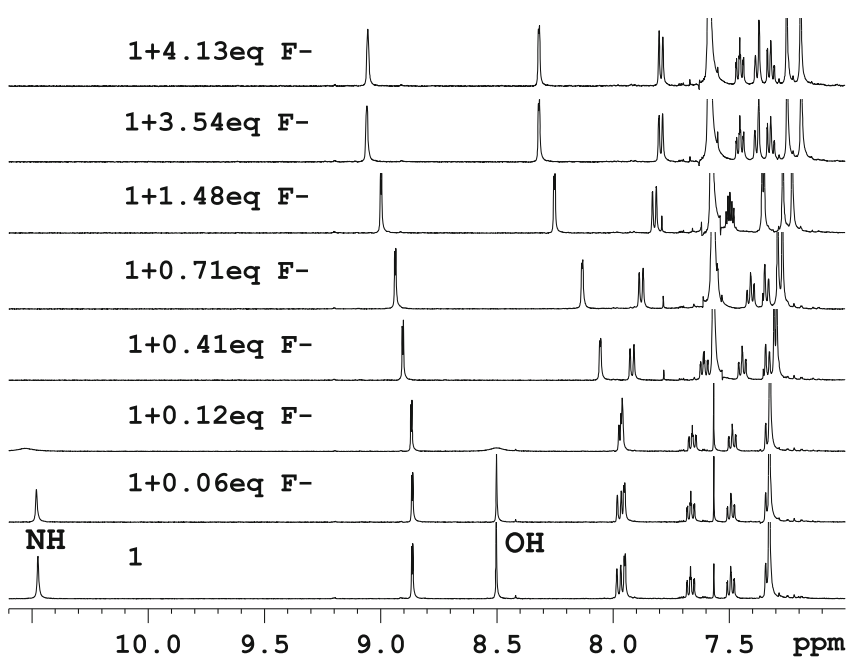

Figure 13. Selected portion of the ${ }^{1} \mathrm{H}$ NMR spectral change for $\mathbf{1 2}$ upon addition of increasing amount of $\mathrm{F}^{-}$. 
few occasions indicate involvement of these protons in anion binding as shown in $\mathbf{1 5}$.

\section{Conclusions}

A large numbers of calixarene-based molecular sensors have been synthesized with variation in size and type of ionophore, shape of cavity, donor atoms, steric crowding, conformation of calix unit and fluorogenic signalling unit. Ion sensing ability of all these new sensor molecules has been investigated with a wide range of cations and anions under different experimental conditions. The ion-recognition process was monitored by different analytical techniques such as luminescence, Uv-vis, NMR spectroscopy and electrochemistry. Binding constant with strongly interacting metal ions have been determined using various spectroscopic titrations. The present study revealed that the factors such as cavity size, donor atoms, steric crowding, conformation of calix moiety and solvent has profound influence in determination of selectivity. Pyrene as fluorophore exhibits strong excimer emission due to $\pi-\pi$ stacking interaction and this band can be used as tool for monitoring the ion-recognition process. Quinoline however, did not show any excimer emission; interestingly it exhibited metal induced excimer emission, which is attributed to the modulation of frontier molecular orbital energies upon complexation with metal ions as suggested by DFT calculations. Another important observation is that a single method of detection is not conclusive to determine the complexing ability of a particular receptor. A sensor molecule having single type of receptor site may act as a multi-ion analyser by using an array of detection methods. For multi-ion sensing, the receptor should exhibit conformational preferences depending on the detection method and in this regard flexible ionophores with multi donor atoms are more suitable.

\section{Supplementary information}

The electronic supporting information (figures S1-S5) can be seen in www.ias.ac.in/chemsci.

\section{Acknowledgements}

Authors are grateful to the Department of Science and Technology (DST), New Delhi Government of India, for financial support. They thank the Council of Scientific and Industrial Research (CSIR), New Delhi for generous support towards infrastructures and core competency development. SP and DM gratefully acknowledge the CSIR for awarding Senior Research
Fellowship (SRF). Thanks are also due to Dr. E Suresh and Dr. B Ganguly for their contributions in crystallography and computational studies, respectively. Authors thank Mr. A K Das, Dr. V P Boricha and Mr. V Agrawal for recording mass, NMR and IR spectra, respectively.

Appendix: Drawings of the chemical structures of the receptors and complexes (1-15).

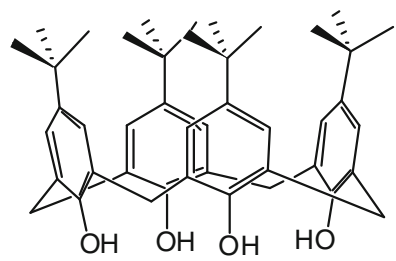

(1)
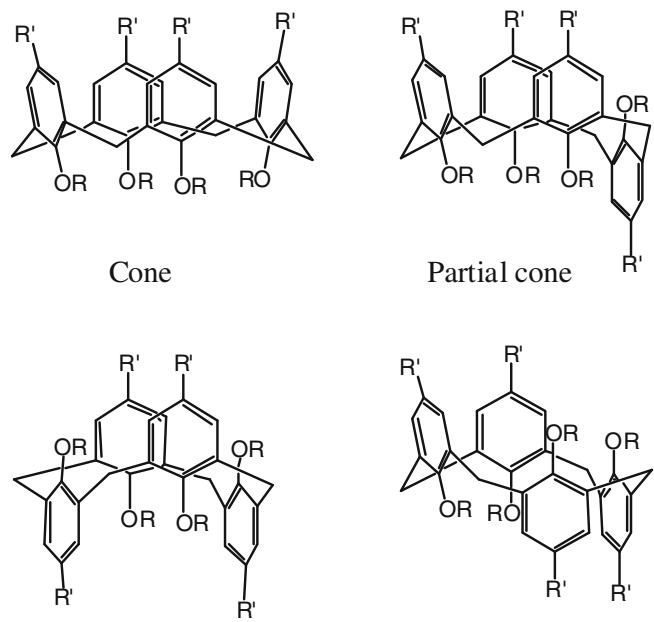

1,3-alternate

1,2-alternate

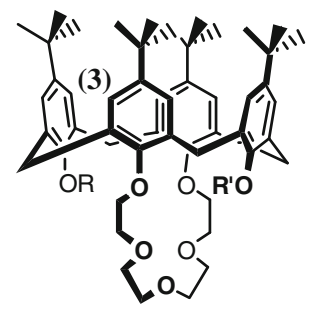

$$
\begin{aligned}
& \mathrm{R}=\mathrm{R}^{\prime}=\mathrm{H} \\
& \mathrm{R}=\mathrm{H}, \mathrm{R}^{\prime}=\mathrm{COCH}_{3} \\
& \mathrm{R}=\mathrm{R}^{\prime}=\mathrm{COCH}_{3} \\
& \mathrm{R}=\mathrm{R}^{\prime}=\mathrm{CH}_{2} \mathrm{CO}_{2} \mathrm{C}_{2} \mathrm{H}_{5} \\
& \mathrm{R}=\mathrm{R}^{\prime}=\mathrm{CH}_{2} \mathrm{CO}_{2} \mathrm{H}
\end{aligned}
$$




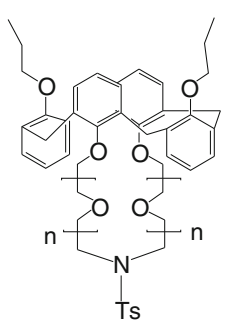

$\mathrm{n}=1$ (a)

$\mathrm{n}=2$ (b)

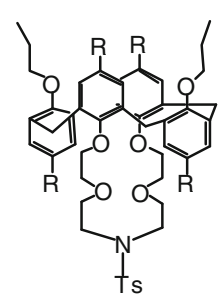

$\mathrm{R}={ }^{\mathrm{t}} \mathrm{Bu}$

(c)

(4)

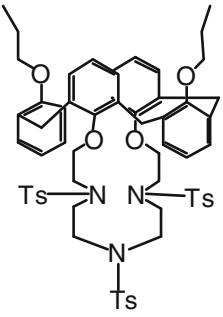

(d)

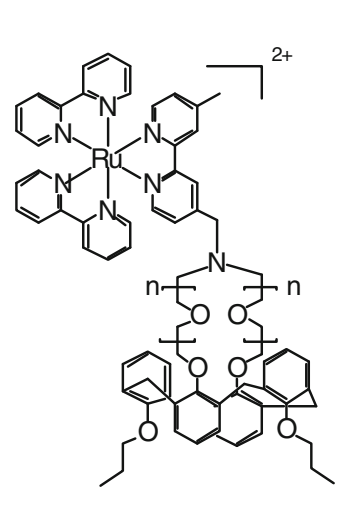

$\mathrm{n}=1$

$\mathrm{n}=2$

(5)

(6)



(7)



(8)

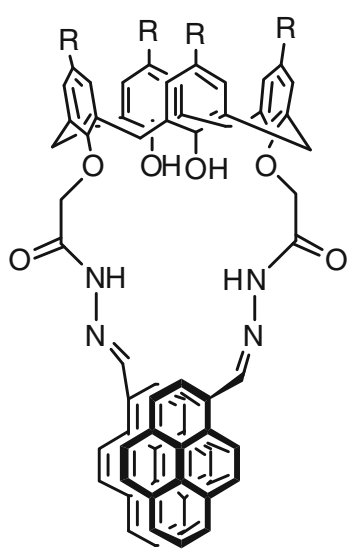

(9)

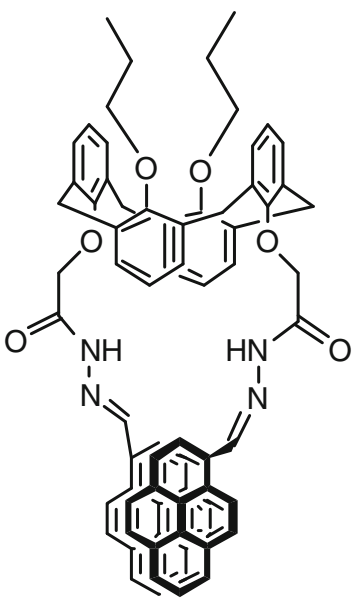

(10) 
1298

Subrata Patra et al.

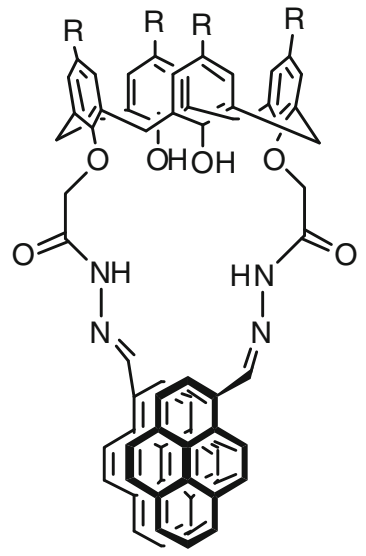

(9)

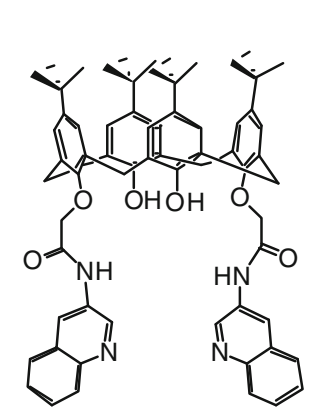

(12)

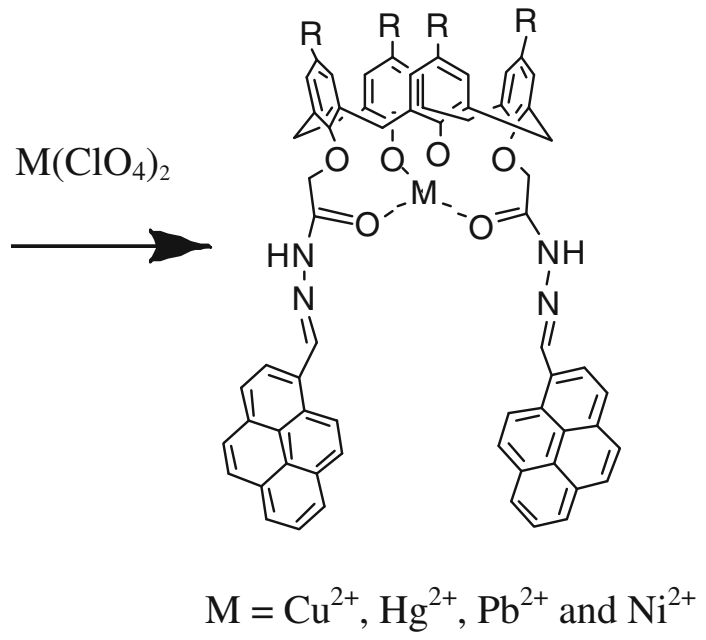

(11)

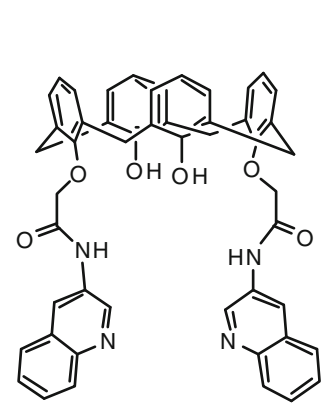

(13)



(14)

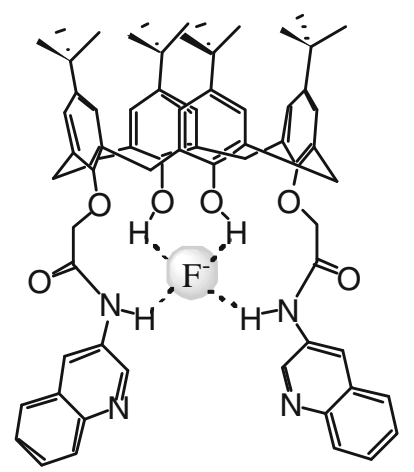

(15) 


\section{References}

1. (a) de Silva A P, Gunaratne H Q N, Gunnlaugsson T, Huxley J M, Mchoy C P, Rademacher J T and Rice T E 1997 Chem. Rev. 97 1515; (b) Beer P D and Gale P A 2001 Angew. Chem. Int. Ed. 40 486; (c) Beer P D and Hayes E 2003 J. Coord. Chem. Rev. 240 167; (d) Yoon J, Kim S K, Sing N J and Kim K S 2006 Chem. Soc. Rev. 35 355; (e) Kim J S and Quang D T 2007 Chem. Rev. 107 3780; (f) Liu Y, Li Z and Guo D S 2009 Supramolecular Chem. 21465

2. (a) Gutsche C D 1989 Calixarenes (Cambridge, UK: The Royal Society of Chemistry); (b) Gutsche C D 1991 Calixarenes, A versatile class of macrocyclic compounds (eds) J Vicens and V BÖhmer) (Dordrecht, Netherlands: Kluwer); (c) BÖhmer V 1995 Angew. Chem. Int. Ed. Engl. 34 713; (d) Gutsche C D 1998 Calixarene revisited (Cambridge, UK: The Royal Society of Chemistry); (e) Gutsche C D 2000 Calixarenes in action (eds) L Mandolini and R Ungaro (London: Imperial College Press); (f) Casnati A, Sansone F and Ungaro R 2003 Calixarene receptors in ion recognition and sensing: Advances in supramolecular chemistry (ed.) G W Gokel (Miami, FL, USA: Cerberus Press Inc.) vol. 9, p. 165; (g) Gutsche C D 2008 Calixarenes: An introduction, 2nd edition (UK: The Royal Society of Chemistry Cambridge)

3. (a) Kim S K, Lee S H, Lee J Y, Lee J Y, Bartsch R A and Kim J S 2004 J. Am. Chem. Soc. 126 16499; (b) Lo P K and Wong M S 2008 Sensors 8 5313; (c) Yuan M, Zhou W, Liu X, Zhu M, Li J, Yin X, Zheng H, Zuo Z, Ouyang C, Liu H, Li Y and Zhu D 2008 J. Org. Chem. 73 5008; (d) Creaven B S and Mcginley D D F 2009 J. Coord. Chem. Rev. 253893

4. (a) Mokhtari Bahram, Pouabdollah Kobra and Dalali Naser 2011 J. Incl. Phenom. Macrocycl Chem. 69 1; (b) Kim Hyun Jung, Lee Min Hee, Mutihac Lucia, Vicens Jacques and Jong Seung Kim 2012 Chem. Soc. Rev. 41 1173; (c) Joseph Roymon and Rao Chebrolu Pulla 2011 Chem. Rev. 1113433

5. Agnihotri P, Suresh E, Paul P and Ghosh P K 2006 Eur. J. Inorg. Chem. 3369

6. Patra S and Paul P 2009 Dalton Trans. 8683

7. Patra S, Suresh E and Paul P 2007 Polyhedron 264971

8. Patra S, Maity D, Sen A, Suresh E, Ganguly B and Paul P 2010 New J. Chem. 342796

9. Maity Debdeep, Chakraborty Ashish, Gunupuru Ravi and Paul P 2011 Inorg. Chim. Acta 372126

10. Patra S, Gunupuru R, Lo R, Suresh E, Ganguly B and Paul P 2012 New J. Chem. 36988
11. (a) Ikeda A, Tsudera T and Shinkai S 1997 J. Org. Chem. 62 3568; (b) Takahashi K, Gunji A, Guillaumont D, Pichierri $\mathrm{F}$ and Nakamura S 2000 Angew. Chem. Int. Ed. 39 2925; (c) Kim J S, Shon O J, Ko J W, Cho M H, Yu I Y and Vicens J 2000 J. Org. Chem. 65 2386; (d) Luo J, Zheng Q-Y, Chen C-F and Huang Z-T 2005 Chem. Eur. J. 11 5917; (e) Lee Y J, Kwon J, Park C S, Lee J-E, Sim W, Kim J S, Seo J, Yoon 11, Jung J H and Lee S S 2007 Org. Lett. 9493

12. (a) Casnati A, Pochini A, Ungaro R, Ugozzoli F, Arnaud F, Fanni S, Schwing M-J, Egberink R J M, de Jong F and Reinhoudt D N 1995 J. Am. Chem. Soc. 117 2767; (b) Casnati A, Pochini A, Ungaro R, Bocchi C, Ugozzoli F, Egberink R J M, Struijk H, Lugtenberg R, Jong F D and Reinhoudt D N 1996 Chem. Eur. J. 2436

13. Hirose K 2001 J. Incl. Phenom. 39193

14. (a) Diamond D and Nolan K 2001 Anal. Chem. 73 22A; (b) Matthews S E, Schmitt P, Felix V, Drew M G B and Beer P D 2002 J. Am. Chem. Soc. 124 1341; (c) Li G-K, Xu Z-X, Chen C-F and Huang Z-T 2008 Chem. Commun. 1774; (d) Dhir A, Bhalla V and Kumar M 2008 Org. Lett. 104891

15. (a) Muegge B D and Richter M M 2002 Anal. Chem. 74 547; (b) Schmittel M, Lin H-W, Thiel E, Meixner A J and Ammon H 2006 Dalton Trans. 4020; (c) Schmittel M and Lin H-W 2007 Angew. Chem. Int. Ed. 119 911; (d) Li M-J, Chen Z, Zhu N, Yam V W-W and Zu Y 2008 Inorg. Chem. 471218

16. (a) Jin T, Ichikawa K and Koyama T 1992 J. Chem. Soc. Chem. Commun. 499; (b) Ludwig R and Dzung N T K 2002 Sensors 2397

17. (a) Lee $\mathrm{S}$ H, Kim S H, Kim S K, Jung J H and Kim J S 2005 J. Org. Chem. 70 9288; (b) Kim S K, Kim S H, Kim H J, Lee S H, Lee S W, Ko J, Bartsch R A and Kim J S 2005 Inorg. Chem. 44 7866; (c) Choi J K, Kim S H, Yoon J, Lee K-H, Bartsch R A and Kim J S 2006 J. Org. Chem. 71 8011; (d) Kim H J, Quang D T, Hong J, Kang G, Ham S and Kim J S 2007 Tetrahedron 63 10788

18. Kumar M, Kumar R and Bhalla V 2009 Tetrahedron 65 4340

19. (a) Ghosh K and Adhikari S 2006 Tetrahedron Lett. 47 3577; (b) Pramanik A and Das G 2009 Tetrahedron 65 2196

20. (a) Lin Z, Zhao Y, Duan C, Zhang B and Bai Z 2006 Chem. Commun. 3678; (b) Lin T, Chen C, Wen Y and Sun S 2007 Inorg. Chem. 46 6427; (c) Shang X, Li J, Lin H, Jiang P, Cai Z and Lin H 2009 Dalton Trans. 2096 